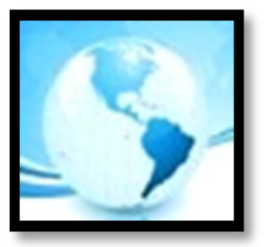

MALAYSIAN ONLINE JOURNAL OF

EDUCATIONAL MANAGEMENT

(MOJEM)

JANUARY 2016, VOLUME 4, ISSUE 1, 64 - 84

E-ISSN NO: $2289-4489$

https://doi.org/10.22452/mojem.vol4no1.5

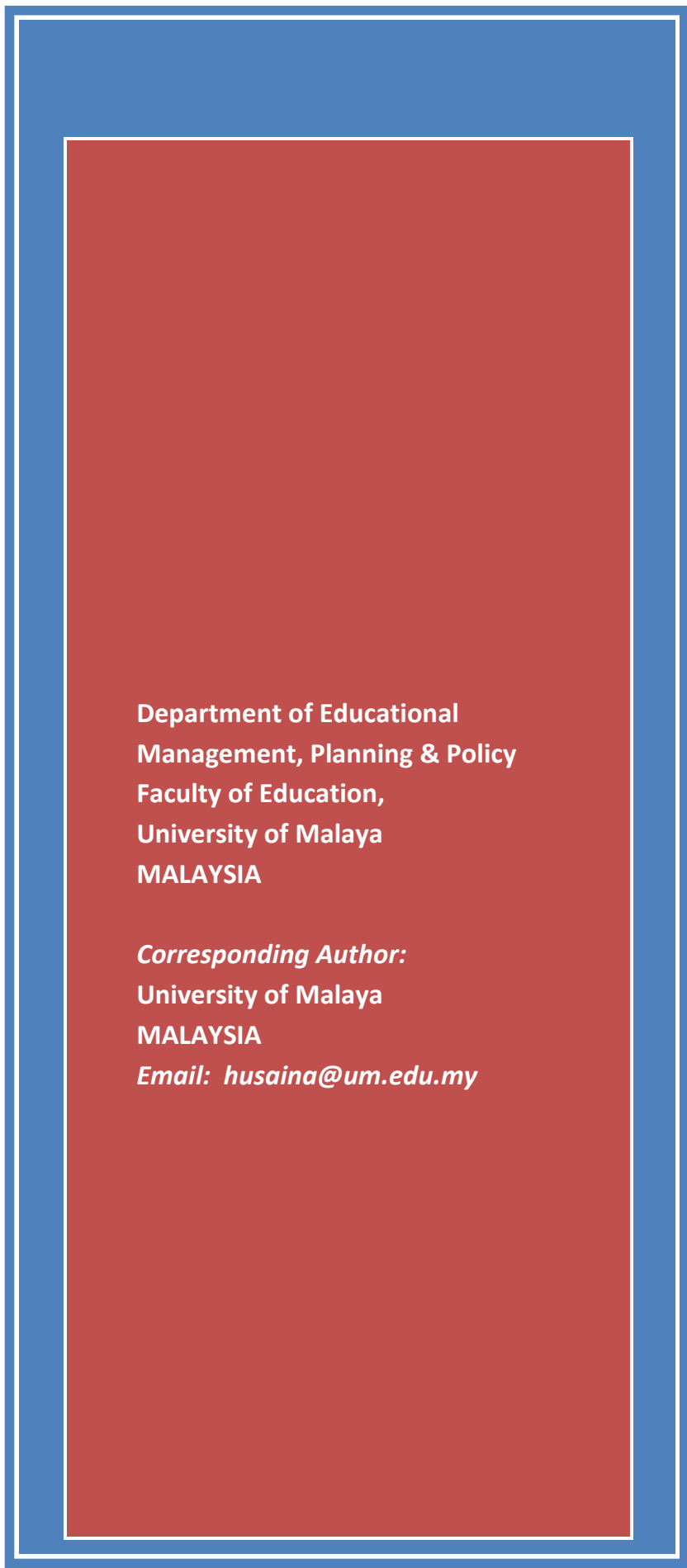

\title{
STUDENT LOANS IN MALAYSIA AND CHINA: EQUITY, EFFICIENCY AND ADEQUACY
}

Husaina Banu Kenayathulla \& Zhang Tengyue

\begin{abstract}
Student loans have been widely practiced in many developed and developing countries to help finance tertiary education. Malaysia and China have advocated student loans to support tertiary education. Such financial assistance helps to reduce the economic burden of students. The objective of this study is to analyze the Malaysian and Chinese student loans in terms of adequacy, equity, efficiency and related issues. Additionally, this study identifies factors that determine adequacy of a student loan in Malaysia and China. Questionnaires were distributed to 200 undergraduate students in Malaysia and China respectively. This study applied descriptive statistics and logistic regression to analyze the data. The findings indicate that the amount of student loans offered should be increased. Both the Malaysian and the Chinese government should concentrate on the equity, efficiency and related issues of student loans. The results also show that nationality, the amount of tuition fees and parental income are important determinants of student loans in Malaysia and China. It is hoped that appropriate policy interventions can be undertaken by policy makers to ensure proper funding for undergraduate students.
\end{abstract}

Keywords: student loans, equity, efficiency, higher education, Malaysia, China 


\section{INTRODUCTION}

Higher education has been considered not only as a public good to improve human capital; to encourage civil involvement; to promote economic growth, but also viewed as a private good which enhances individual's life in the past decades (UNESCO, 2009). At the beginning of the 21st century, higher education encountered the unprecedented demand from individuals, families, the occupational and social status and also the government (Word Bank, 2012). Through higher education, the quality of people's life will be improved, society will become more harmonious and the economic development of the country will increase steadily and continuously (Pavel, 2012) Therefore, individuals, society and the country will benefit from higher education (Baum \& Payea, 2004).

National agendas have been concentrated upon higher education. In order to encourage students to attend and graduate from college and university, both developed and developing countries have implemented various financial aids such as student loans, scholarships, grants, and work-study programs. Scholarships are offered to students based on students' talent, skills, and academic performance. Grants are provided to students who express the expectation of financial needs, but the grant is almost replaced by student loan in recent years. Workstudy programs provide work opportunities to students so that the students can get a salary to support their studies. Moreover, student loans are offered to students, especially those who are from lower-income families to pay education-related expenditures such as tuition fees and living expenses. The borrowers are required to repay the loan with lower interest rates after graduation. In this case, financial aids play a crucial role in providing access to higher education (Hossler, Gross \& Ziskin, 2006).

Since the tuition fees keep increasing, a substantial number of students from lower income families encounter problems in making decisions related to educational investments. (Executive Office of the President, 2014).This is because they do not have the financial capacity to pursue higher education. With the implementation of student loans, students from lower socio-economic backgrounds will have equality of opportunity to pursue higher education. Previous studies mentioned that student loans are a way to lessen the economic burden (Ziderman, 2002). Moreover, it is also a way to realize the equality of education.

The Malaysian National Higher Education Action Plan 2007-2010 emphasized on the transformation of higher education. The government and the ministry of education of Malaysia have implemented various financial aid programs such as grants, scholarships, student loans and work-study programs. For instance: a PTPTN loan in Malaysia has been provided for students to pursue their higher education at the undergraduate, postgraduate, doctorate or professional courses in the established higher institutions. This loan will support students to pay tuition fees and living expenses.

In China, the Ministry of Education in the 1998s emphasized that both central and local governments should provide financial aids to support students. The central government should pay attention to centrally controlled institutions and the local government should focus on the locally controlled institutions. From 1987 to 2002, the China government has implemented various financial aid programs. For instance, the subsidy program for poor students was introduced by the government in 1993; a program of work-study in 1994; and a tuition reduction program in 1995 (Wang et al., 2008). In recent years, student loans in China are advocated by both the national government and higher institutions. The availability of student loans enables students to pursue tertiary education. 


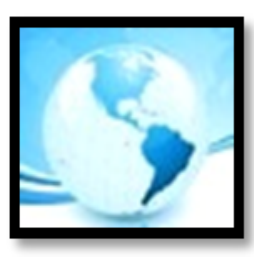

\section{MALAYSIAN ONLINE JOURNAL OF EDUCATIONAL MANAGEMENT (MOJEM)}

Even though, the implementation of student loans has been prioritized by the government, the amount of loan is still inadequate to cover both the tuition fees and living expenses; the repayment of student loan is still a big burden that affects the borrowers' decision-making in daily life.

\section{Higher Education System in Malaysia and China}

Higher education represents a crucial element in the development of human capital and innovation. It also plays a central role in success and sustainability of knowledge and economy (Dill \& Van Vught, 2010). Moreover, it is also a way for an individual to increase their personal capability, sense and consciousness (Zhang, 2008).

Higher education in Malaysia is mainly divided into public and private institutions. The public higher institutions are operated by self-management and partially funded by the government. The private higher institutions are also governed by self-management, but the difference is the private higher institutions include the private universities and colleges, the open universities, the virtual universities, and the international universities with branches in Malaysia (Levy, 2010). The Malaysian Higher education was established in 2004 with the guidance of the Ministry of Higher Education (MOHE). There were 20 public universities, 37 community colleges and 21 polytechnics, 32 private universities colleges, and 485 private colleges were established in Malaysia (Ministry of Higher Education, 2010). The normal period of university education is three to four years (Ismail et al., 2010). And the Malaysian students have self-option to choose and enroll in different higher institutions.

In China, the higher education system is centralized. All the higher institutions are managed and controlled by the Ministry of Education via policy-making, legislation, planning, funding, and evaluation. According to statistical report, there are 3000 higher institutions in China which have 25.4 million enrollments. Among all, 1867 standard higher institutions are established, the total rate of enrollment is 17.4 million while 444 vocational institutions consist of 5.2 million enrollment; there are also 1789 private institutions which show the total enrollment of 2.8 (Ministry of Education, 2006).

Higher education has encountered the unprecedented demand from individuals and families, the occupational and social status as well as the government. The UNESCO Institute for Statistics (UIS) in 1970 forecasted that there are 32.5 million students worldwide enrolled in higher education. Until 2000, this estimation increased to nearly 100 million and then increased to 178 million in 2010. This translates into $4.3 \%$ average annual growth in tertiary enrolment, a rapid growth when compared to the $1.6 \%$ average annual growth in the world population over the same period (UNDP, 2012).

\section{CONCEPTUAL FRAMEWORK}

Previously higher education finance has focused on equity and efficiency. However, in recent years, the emphasis has also been on adequacy of student loans. The conceptual framework has been developed based on the equity, efficiency and adequacy concept of student loan (Johnstone, 2006; Ziderman, 2003). 


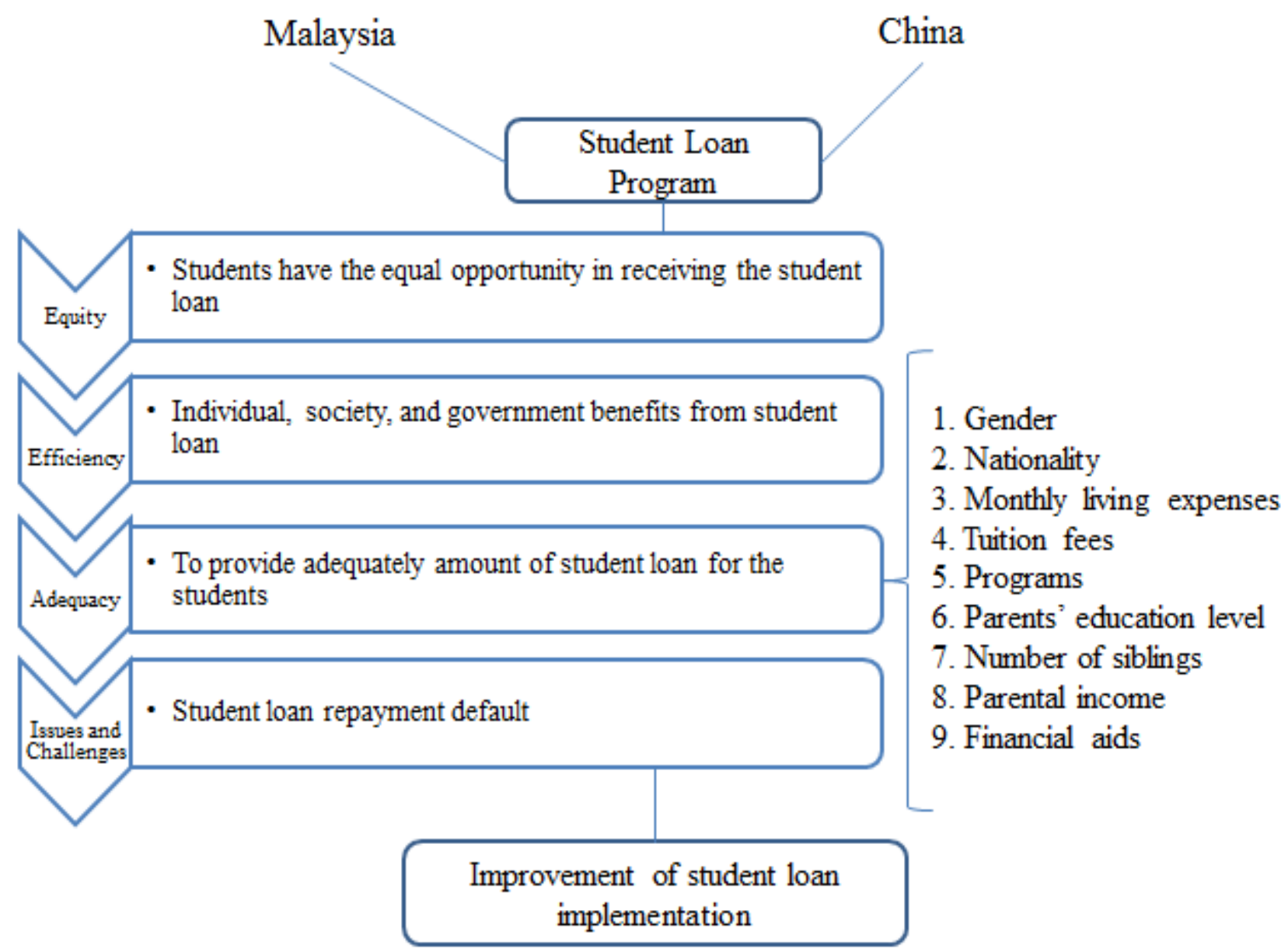

Figure 1. The conceptual framework of the study (source: Johnstone, 2006; Ziderman, 2003)

Both developed and developing countries have established several educational policies to ensure that students have equality of opportunity to pursue higher education. In recent years, most countries have concentrated on student loan, and recommended student loans to students, especially for those low-income families. Student loans help reduce the economic burden of students as well as the governments. However, the default in loan repayment has become an important phenomenon in recent years. Because of the unemployment rates, personal family background, debt burden, and personal attitudes, the default rates in payment of student loan have increased recently. 


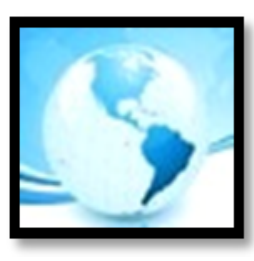

\section{MALAYSIAN ONLINE JOURNAL OF EDUCATIONAL MANAGEMENT (MOJEM)}

\section{The Adequacy of Student Loans}

Student loans help finance tertiary education for students with diverse backgrounds. Thus, it is important to ensure that the student loans are adequate. According to Feng (2009), the amount of student loan should be adequate to ensure students can rely on it. Adequate amount of student loans will help students to complete their studies (Liu, Cheng \& Zhang, 2007). Inadequate amount of funding might result in students working part time to support their education or dropout during their studies

\section{The Equity of Student Loans}

Student loans aim to provide equality of opportunity for students, especially those who come from low-income families. For instance: the Government-Subsidized Student Loans Scheme aims to help poor students to pay tuition and living fees. The loan receivers should be the students whose personal income or family income is inadequate to pay the education-related expenses during their study (Macmillan, 2006).

However, it is questionable whether student loans are reaching the targeted recipients. Especially in countries like Mainland China, Thailand, Philippines and Korea, increasing number of upper-income students are applying for student loans since it is given based on merit (Feng, 2009). Students who are ineligible but can obtain the loans because of the unclear definition of student eligibility and abuse of the loan administration system (Shen \& Li, 2003). Ziderman (2003), asserts that this is "wasteful and inequitable". Alternatively, a study shows that only half of needy students in China applied for loans due to debt aversion or other reasons.

\section{The Efficiency of Student Loans}

Student loans have been implemented in both developed and developing countries. Around the world, 70 countries have been operating the program of student loans by the government-sponsored, and a number of countries are also considering and are determined to introduce the student loans program immediately (Shen \& Ziderman, 2009).

The efficiency of student loans reflect that it can be applied to reduce the budget demands of governments or taxpayers; it can serve as an additional resource to fund the expansion of higher education to enlarge access and to achieve the education equality; it also provides more opportunities for students, especially the low-income family students to attend higher education.

For students, student loans can be relied to encourage the increasing number of students from low-income families to attend the higher education via the increased enrollment (Nyahende, 2013). For instance: the program of student loans in Tanzania is known as higher education students' loans board (HESLB) which was established under the act of parliament No. 9 of 2004, as amended by act No. 9 of 2007, CAP 178 and commenced its operation in July, 2005. Since the HESLB was introduced, the number of enrollments of students from low-income families to higher institutions has increased significantly (Ishengoma, 2004). According to Ziderman (2004), student loans are targeted to lower socio-economic groups and also disadvantaged groups.

Likewise, the government also can obtain various benefits from student loans, for instance: the repayment of loans by the graduates will enable a huge amount of funds to be mobilized in a short period; the allocations of budget can be reduced by the government gradually, and ultimately the government will be disaffiliated from financing 


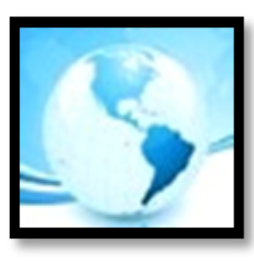

\section{MALAYSIAN ONLINE JOURNAL OF EDUCATIONAL MANAGEMENT (MOJEM)}

higher education; and the revolving funds can be formed to support the higher education (Johnstone, 2006). Johnstone and Marcucci (2010) stated that student loans not only enhance the access to higher education, but also reduce the regressive distribution of public resources. This is because all borrowers whose education is supported by the student loans are obliged to repay the loan. Compared to the system of scholarship grants, free tuition-fees, and financed by the government revenue, student loans lead to a more equitable sharing in the costs of higher education (Woodhall, 2007).

\section{The Issues and Challenges of Student Loans}

Student loan programs are established to support the economic status for the poor students as well as to help the government share the costs and reduce the burden of the educational budget. The phenomenon that students rely on loans to access higher institutions in recent years is becoming widespread. Due to the increasing number of student loans offered, the concerns regarding students' capability to repay the loan has also been increased. During the process of HEA Reauthorization in 1986 student loan default was a key issue (Gross, Cekic, Hossler \& Hillman, 2009). Moreover, one of the examples in 2001 showed that the number of defaulted student loan has already exceeded to US\$25 billion (Seifert \& Worden, 2004). Therefore, the relevant sectors such as the higher institutions and governments are struggling to deal with the increasing problem of education debt.

\section{Highly Rate of Unemployment}

One of the pivotal factors in the high rate of loan repayment defaults is due mostly to unemployment. Unemployment will reduce the amount of income, and the reason why there are more students prefer to default the loan repayment is that their personal income is inadequate to assign to the repayment (Woo, 2002a, 2002b). Therefore, a large proportion of unemployed borrowers default on their student loans. For instance: one of the studies in 2002 shows that the rate of student loans default from borrowers in California is totally 32.9 percent including 23.2 percent for those who had applied for unemployment compensation, compared to 9.7 percent for those who had not (Woo, 2002).

\section{Family Economic-support}

If unemployment can lead borrowers to default the loan repayments, then, the wealthy family economic-support will be another way to increase the rate of loan repayment default. According to Herr and Burt (2005); Steiner and Teszler (2005), the students who come from low-income families are undertaking more debt burden than their wealthy peers. And they will feel the pressure at the beginning of loan repayment (Baum \& O'Malley, 2003b). Compared with the needy peers, the students from high-income family will receive more economic-support, so there is a lower likelihood of higher-income students to default the loan repayments (Woo, 2002a, 2002b), and relatively, a higher likelihood of low-income students seem to default loan repayments more frequently.

\section{Burden of Debt}

Research also emphasizes that debt burden will increase the proportions of loan repayment default. According to Choy and Li (2006), there were 11 percent of the borrowers suffering from the unmanageable debt status in 2003, and more than 20 percent of the borrowers ultimately default. Generally, if the burden of debt exceeds 8 percent of the income per month, it means that the debt is unmanageable. Therefore, those students who owe more money have difficulty in loan repayment (Schwartz \& Finnie, 2002). 


\section{Negative Attitude towards Loan Repayment}

According to Bertola and Hochguertel (2005), loan default occurs partially due to the lack of attention to pay. Once the borrowers get the first job and salary, they will be more likely to repay other debts such as credit cards, a car loan or a housing loan. A survey researching 1500 undergraduates from the University Putra Malaysia shows that many students considered student loans as a big burden and a comparative proportion of students have negative attitudes towards loan repayment (Elistina et al., 2006).

Some authors argue that the student loan is flexible since repayment can be made with a lower interest (Barr, 2001). The regulations actually allow borrowers to delay the loan repayment when they are in dilemma, but many of distressed borrowers do not concentrate on it (Cunningham \& Kienzl, 2011). For instance: PTPTN loan is one of the government loan programs in Malaysia, which allows borrowers to repay the loan along with the low interest starting six months after graduation. This kind of requirement actually gives the borrowers time to find ways to repay the loan (i.e find a job firstly). Moreover, during the tabling of Budget 2015, Prime Minister Datuk Seri Najib Tun Razak announced that the borrowers of National Higher Education Fund Corporation (PTPTN) loan will be given a 20 percent discount if they make the full repayment at once by March 31 in the next year. Moreover, the borrowers who fail to do so can still obtain 10 percent discount if they make continuous payments for 12 months until December 31 of 2016 (Ministry of Higher Education, 2015)

\section{RESEARCH QUESTIONS}

This study was designed to explore the student loan in terms of adequacy; equity; efficiency; issues and challenges, and the factors which determine the adequacy of financial aid in selected higher Institutions in both Malaysia and China. Accordingly, research questions are mentioned in the following:

1. What are the challenges encountered in student loans in Malaysia and China in terms of adequacy, equity, efficiency and related issues?

2. What are the factors that determine adequacy in student loans in Malaysia and China?

\section{METHOD}

\section{Research Design}

In this study, a quantitative research design was chosen. The survey method was employed to ensure wider distribution of samples and it is representative of the population (Creswell, 2013). The questionnaires were distributed to respondents in order to collect data. Because this study is a comparative study which compares student loans in both Malaysia and China, thus, the questionnaires were distributed respectively to Malaysia and China, and the language which was used in the questionnaires is English for Malaysia and Chinese for China. 


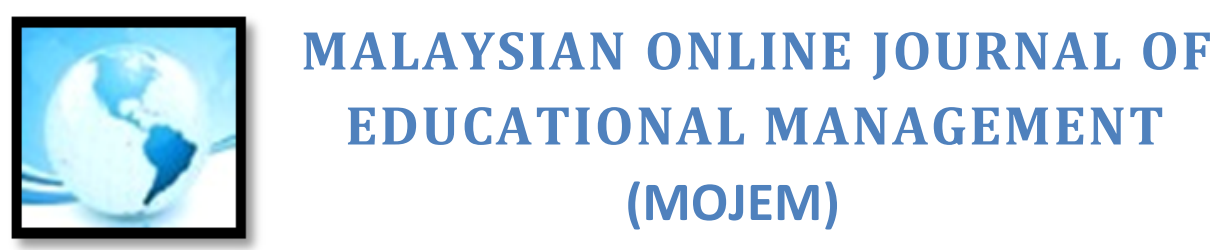

Moreover, the questionnaires were distributed at a renowned public university in each country, and all respondents were undergraduate students.

\section{Sampling}

This study identifies the student loan programs in the selected higher institutions in both Malaysia and China from the micro perspectives; therefore, the population of this study was the undergraduate students who study in the university in Kuala Lumpur of Malaysia and in Peking of China.

Sampling is a process of selecting subjects who are a representative of the population being studied (Creswell, 2013). The sample in this study consists of 400 undergraduate students who are currently studying in university. Because this study is a comparative study which compares the phenomenon in both Malaysia and China, thus, the total 400 samples were allocated 200 in each country equally.

Only those students in undergraduate courses were chosen as the sample in this study. Both Chinese and Malaysian universities offer post-graduate education. Compared with other two types of students, undergraduate students need more economic support regardless whether such support is from their family or subsidized,

\section{Data Collection Procedures}

A permission letter was obtained from the university in Malaysia whereas there is no such requirement in China. Once the permission letter was obtained, the researcher distributed the questionnaires to the undergraduate students randomly. Another set of questionnaires were distributed to a professor in China. When the questionnaires were distributed to participants, the researcher concisely explained the purpose of the study and asked for the participants to attend the research. Participants' related information is maintained anonymously and the researcher encouraged the participants to act honestly.

\section{Data Analysis Process}

Table 1

The research method for each research question

\begin{tabular}{|l|c|}
\hline \multicolumn{1}{|c|}{ Research Objectives: } & Statistical Methods: \\
\hline RO1: To analyze the challenges encountered in relation to student loans in \\
Malaysia and China in terms of equity, efficiency, adequacy and related \\
issues
\end{tabular}

Both descriptive statistics and inferential statistics such as logistic regression are used in this study. The statistical methods are chosen and utilized according to the research questions. 


\section{FINDINGS}

Research Question 1: What are the challenges encountered in student loans in Malaysia and China in terms of adequacy, equity, efficiency and related issues?

\section{The Adequacy of Student Loans}

Table 2

Frequency, Percentage and Mean of Adequacy of Student Loan

\begin{tabular}{|c|c|c|c|c|c|c|c|c|c|c|c|c|}
\hline \multirow[t]{2}{*}{ Adequacy } & \multicolumn{6}{|c|}{ MALAYSIA } & \multicolumn{6}{|c|}{ CHINA } \\
\hline & $\begin{array}{l}\text { SD } \\
\text { F } \\
(\%)\end{array}$ & $\begin{array}{l}\text { D } \\
\text { F } \\
(\%)\end{array}$ & $\begin{array}{l}\mathbf{N} \\
\mathrm{F} \\
(\%)\end{array}$ & $\begin{array}{l}\mathbf{A} \\
\mathrm{F} \\
(\%)\end{array}$ & $\begin{array}{l}\text { SA } \\
\text { F } \\
(\%)\end{array}$ & $\begin{array}{l}\text { Mean } \\
\text { F } \\
(\mathrm{M})\end{array}$ & $\begin{array}{l}\text { SD } \\
\text { F } \\
(\%)\end{array}$ & $\begin{array}{l}\text { D } \\
\text { F } \\
(\%)\end{array}$ & $\begin{array}{l}\mathbf{N} \\
\text { F } \\
(\%)\end{array}$ & $\begin{array}{l}\mathbf{A} \\
\mathrm{F} \\
(\%)\end{array}$ & $\begin{array}{l}\text { SA } \\
\text { F } \\
(\%)\end{array}$ & $\begin{array}{l}\text { Mean } \\
\text { F } \\
(\mathrm{M})\end{array}$ \\
\hline $\begin{array}{l}\text { 1. Money covers } \\
\text { tuition fees, or living } \\
\text { fees. }\end{array}$ & $\begin{array}{l}17 \\
(8.5)\end{array}$ & $\begin{array}{l}39 \\
(19.5)\end{array}$ & $\begin{array}{l}0 \\
(0)\end{array}$ & $\begin{array}{l}83 \\
(41.5)\end{array}$ & $\begin{array}{l}61 \\
(30.5)\end{array}$ & 3.66 & $\begin{array}{l}0 \\
(0)\end{array}$ & $\begin{array}{l}22 \\
(11)\end{array}$ & $\begin{array}{l}0 \\
(0)\end{array}$ & $\begin{array}{l}118 \\
(59)\end{array}$ & $\begin{array}{l}60 \\
(30)\end{array}$ & 4.08 \\
\hline $\begin{array}{l}\text { 2. Money covers } \\
\text { both tuition and } \\
\text { living fees. }\end{array}$ & $\begin{array}{l}21 \\
(10.5)\end{array}$ & $\begin{array}{l}107 \\
(53.5)\end{array}$ & $\begin{array}{l}2 \\
(1)\end{array}$ & $\begin{array}{l}52 \\
(26)\end{array}$ & $\begin{array}{l}18 \\
(9)\end{array}$ & 2.7 & $\begin{array}{l}9 \\
(4.5)\end{array}$ & $\begin{array}{l}123 \\
(61.5)\end{array}$ & $\begin{array}{l}0 \\
(0)\end{array}$ & $\begin{array}{l}68 \\
(34)\end{array}$ & $\begin{array}{l}0 \\
(0)\end{array}$ & 2.64 \\
\hline $\begin{array}{l}\text { 3. I take part-time } \\
\text { job to support my } \\
\text { studies. }\end{array}$ & $\begin{array}{l}24 \\
(12)\end{array}$ & $\begin{array}{l}83 \\
(41.5)\end{array}$ & $\begin{array}{l}0 \\
(0)\end{array}$ & $\begin{array}{l}70 \\
(35)\end{array}$ & $\begin{array}{l}23 \\
(11.5)\end{array}$ & 2.93 & $\begin{array}{l}28 \\
(14)\end{array}$ & $\begin{array}{l}160 \\
(80)\end{array}$ & $\begin{array}{l}0 \\
(0)\end{array}$ & $\begin{array}{l}12 \\
(6)\end{array}$ & $\begin{array}{l}0 \\
(0)\end{array}$ & 1.98 \\
\hline $\begin{array}{l}\text { 4. I still need } \\
\text { parents' support. }\end{array}$ & $\begin{array}{l}26 \\
(13)\end{array}$ & $\begin{array}{l}41 \\
(20.5)\end{array}$ & $\begin{array}{l}0 \\
(0)\end{array}$ & $\begin{array}{l}99 \\
(49.5)\end{array}$ & $\begin{array}{l}34 \\
(17)\end{array}$ & 3.4 & $\begin{array}{l}0 \\
(0)\end{array}$ & $\begin{array}{l}44 \\
(22)\end{array}$ & $\begin{array}{l}0 \\
(0)\end{array}$ & $\begin{array}{l}144 \\
(72)\end{array}$ & $\begin{array}{l}0 \\
(0)\end{array}$ & 3.32 \\
\hline $\begin{array}{l}\text { 5. The amount of } \\
\text { student loan is not } \\
\text { adequate. }\end{array}$ & $\begin{array}{l}21 \\
(10.5)\end{array}$ & $\begin{array}{l}18 \\
(9)\end{array}$ & $\begin{array}{l}0 \\
(0)\end{array}$ & $\begin{array}{l}91 \\
(45.5)\end{array}$ & $\begin{array}{l}70 \\
(35)\end{array}$ & 3.86 & $\begin{array}{l}0 \\
(0)\end{array}$ & $\begin{array}{l}27 \\
(13.5)\end{array}$ & $\begin{array}{l}50 \\
(25)\end{array}$ & $\begin{array}{l}90 \\
(45)\end{array}$ & $\begin{array}{l}33 \\
(16.5)\end{array}$ & 3.65 \\
\hline $\begin{array}{l}\text { 6. The amount of } \\
\text { student loans } \\
\text { should vary } \\
\text { according to the } \\
\text { courses. }\end{array}$ & $\begin{array}{l}0 \\
(0)\end{array}$ & $\begin{array}{l}26 \\
(13)\end{array}$ & $\begin{array}{l}0 \\
(0)\end{array}$ & $\begin{array}{l}152 \\
(76)\end{array}$ & $\begin{array}{l}22 \\
(11)\end{array}$ & 3.85 & $\begin{array}{l}0 \\
(0)\end{array}$ & $\begin{array}{l}0 \\
(0)\end{array}$ & $\begin{array}{l}0 \\
(0)\end{array}$ & $\begin{array}{l}178 \\
(89)\end{array}$ & $\begin{array}{l}22 \\
(11)\end{array}$ & 4.11 \\
\hline $\begin{array}{l}\text { 7. The amount of } \\
\text { student loans } \\
\text { should be need } \\
\text { based. }\end{array}$ & $\begin{array}{l}8 \\
(4)\end{array}$ & $\begin{array}{l}40 \\
(20)\end{array}$ & $\begin{array}{l}0 \\
(0)\end{array}$ & $\begin{array}{l}130 \\
(65)\end{array}$ & $\begin{array}{l}22 \\
(11)\end{array}$ & 3.59 & $\begin{array}{l}0 \\
(0)\end{array}$ & $\begin{array}{l}5 \\
(2.5)\end{array}$ & $\begin{array}{l}0 \\
(0)\end{array}$ & $\begin{array}{l}96 \\
(48)\end{array}$ & $\begin{array}{l}99 \\
(49.5)\end{array}$ & 4.45 \\
\hline $\begin{array}{l}8 . \text { The poor } \\
\text { students should } \\
\text { have priority to } \\
\text { receive more } \\
\text { money. }\end{array}$ & $\begin{array}{l}21 \\
(10.5)\end{array}$ & $\begin{array}{l}13 \\
(6.5)\end{array}$ & $\begin{array}{l}0 \\
(0)\end{array}$ & $\begin{array}{l}88 \\
(44)\end{array}$ & $\begin{array}{l}78 \\
(39)\end{array}$ & 3.95 & $\begin{array}{l}0 \\
(0)\end{array}$ & $\begin{array}{l}62 \\
(31)\end{array}$ & $\begin{array}{l}0 \\
(0)\end{array}$ & $\begin{array}{l}100 \\
(50)\end{array}$ & $\begin{array}{l}38 \\
(19)\end{array}$ & 3.6 \\
\hline
\end{tabular}




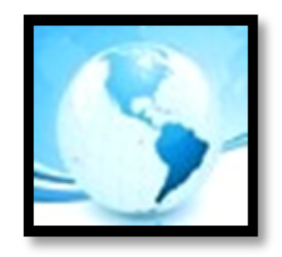

(MOJEM)

\begin{tabular}{|c|c|c|c|c|c|c|c|c|c|c|c|c|}
\hline $\begin{array}{l}\text { 9. The amount of } \\
\text { student loans is } \\
\text { adequate to support } \\
\text { my pocket money. }\end{array}$ & $\begin{array}{l}14 \\
\text { (7) }\end{array}$ & $\begin{array}{l}84 \\
(42)\end{array}$ & $\begin{array}{l}2 \\
(1)\end{array}$ & $\begin{array}{l}81 \\
(41.5)\end{array}$ & $\begin{array}{l}19 \\
(9.5)\end{array}$ & 3.04 & $\begin{array}{l}18 \\
(9)\end{array}$ & $\begin{array}{l}145 \\
(72.5)\end{array}$ & $\begin{array}{l}0 \\
(0)\end{array}$ & $\begin{array}{l}37 \\
(18.5)\end{array}$ & $\begin{array}{l}0 \\
(0)\end{array}$ & 2.28 \\
\hline $\begin{array}{l}\text { 10. Students' } \\
\text { economic burden is } \\
\text { relieved through } \\
\text { student loan. }\end{array}$ & $\begin{array}{l}8 \\
(4)\end{array}$ & $\begin{array}{l}32 \\
(16)\end{array}$ & $\begin{array}{l}2 \\
(2)\end{array}$ & $\begin{array}{l}128 \\
(64)\end{array}$ & $\begin{array}{l}30 \\
(15)\end{array}$ & 3.7 & $\begin{array}{l}0 \\
(0)\end{array}$ & $\begin{array}{l}32 \\
(16)\end{array}$ & $\begin{array}{l}0 \\
(0)\end{array}$ & $\begin{array}{l}125 \\
(62.5)\end{array}$ & $\begin{array}{l}43 \\
(21.5)\end{array}$ & 3.9 \\
\hline
\end{tabular}

Note. $\mathrm{F}=400$; Percentage are in parentheses *Mean value $(\mathrm{M})>3.00$ indicates agree; Mean value $(\mathrm{M})<3.00$ indicates disagree

As can be seen clearly in Table 2, the mean of (3.66) in Malaysia and (4.08) in China shows that most respondents agree that the student loan is only adequate to cover their tuition fees, or living fees. The mean of (2.70) in Malaysia and (2.64) in China shows that most respondents disagree with the statement that money is adequate to cover their tuition fees and living fees. Therefore, the mean of (3.86) in Malaysia and (3.65) in China shows that most respondents agree with student loan and that the amount needs to be increased. Moreover, the mean of (3.85) and (3.59) in Malaysia shows that most respondents agree that the student loan should vary according to the courses and also need based. Similar findings are also observed in China. The mean is (4.11) and (4.45). Accordingly, the mean of (3.95) in Malaysia and (3.60) in China shows that most respondents agree with the statement that the poor students should have priority to receive more allocations.

\section{The Equity of Student Loans}

Table 3

Frequency, Percentage and Mean of Equity of Student Loan

\begin{tabular}{|c|c|c|c|c|c|c|c|c|c|c|c|c|}
\hline \multirow[t]{4}{*}{ Adequacy } & \multicolumn{6}{|c|}{ MALAYSIA } & \multicolumn{6}{|c|}{ CHINA } \\
\hline & SD & D & $\mathbf{N}$ & $\mathbf{A}$ & SA & Mean & SD & D & $\mathbf{N}$ & $\mathbf{A}$ & SA & Mean \\
\hline & $\mathrm{F}$ & $\mathrm{F}$ & $\mathrm{F}$ & $\mathrm{F}$ & $\mathrm{F}$ & & $\mathrm{F}$ & $\mathrm{F}$ & $\mathrm{F}$ & $\mathrm{F}$ & $\mathrm{F}$ & \\
\hline & $(\%)$ & $(\%)$ & $(\%)$ & $(\%)$ & (\%) & $(\mathrm{M})$ & (\%) & $(\%)$ & $(\%)$ & $(\%)$ & (\%) & $(\mathrm{M})$ \\
\hline $\begin{array}{l}\text { 1. All students in } \\
\text { the university are } \\
\text { allowed to apply } \\
\text { for student loan. }\end{array}$ & $\begin{array}{l}21 \\
(10.5)\end{array}$ & $\begin{array}{l}64 \\
(32)\end{array}$ & $\begin{array}{l}0 \\
(0)\end{array}$ & $\begin{array}{l}72 \\
(36)\end{array}$ & $\begin{array}{l}43 \\
(21.5)\end{array}$ & 3.26 & $\begin{array}{l}4 \\
(2)\end{array}$ & $\begin{array}{l}68 \\
(34)\end{array}$ & $\begin{array}{l}0 \\
(0)\end{array}$ & $\begin{array}{l}105 \\
(52.5)\end{array}$ & $\begin{array}{l}23 \\
(11.5)\end{array}$ & 3.38 \\
\hline $\begin{array}{l}\text { 2. Students have } \\
\text { same opportunity } \\
\text { to receive student } \\
\text { loan. }\end{array}$ & $\begin{array}{l}6 \\
\text { (3) }\end{array}$ & $\begin{array}{l}21 \\
(10.5)\end{array}$ & $\begin{array}{l}0 \\
(0)\end{array}$ & $\begin{array}{l}91 \\
(45.5)\end{array}$ & $\begin{array}{l}82 \\
(41)\end{array}$ & 4.11 & $\begin{array}{l}53 \\
(26.5)\end{array}$ & $\begin{array}{l}134 \\
(67)\end{array}$ & $\begin{array}{l}0 \\
(0)\end{array}$ & $\begin{array}{l}13 \\
(6.5)\end{array}$ & $\begin{array}{l}0 \\
(0)\end{array}$ & 1.87 \\
\hline $\begin{array}{l}\text { 3. Student loan is } \\
\text { provided based on } \\
\text { family income } \\
\text { status }\end{array}$ & $\begin{array}{l}17 \\
(8.5)\end{array}$ & $\begin{array}{l}41 \\
(20.5)\end{array}$ & $\begin{array}{l}0 \\
(0)\end{array}$ & $\begin{array}{l}84 \\
(42)\end{array}$ & $\begin{array}{l}58 \\
(29)\end{array}$ & 3.63 & $\begin{array}{l}0 \\
(0)\end{array}$ & $\begin{array}{l}56 \\
(28)\end{array}$ & $\begin{array}{l}0 \\
(0)\end{array}$ & $\begin{array}{l}106 \\
(53)\end{array}$ & $\begin{array}{l}38 \\
(19)\end{array}$ & 3.63 \\
\hline
\end{tabular}




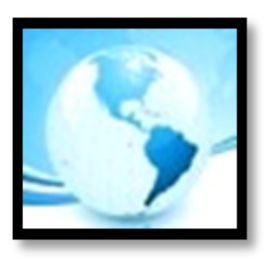

(MOJEM)

\begin{tabular}{|c|c|c|c|c|c|c|c|c|c|c|c|c|}
\hline $\begin{array}{l}\text { 4. Student loan is } \\
\text { provided based on } \\
\text { students' } \\
\text { academic } \\
\text { performance. }\end{array}$ & $\begin{array}{l}19 \\
(9.5)\end{array}$ & $\begin{array}{l}68 \\
(34)\end{array}$ & $\begin{array}{l}0 \\
(0)\end{array}$ & $\begin{array}{l}71 \\
(35.5)\end{array}$ & $\begin{array}{l}42 \\
(21)\end{array}$ & 3.27 & $\begin{array}{l}6 \\
(3)\end{array}$ & $\begin{array}{l}75 \\
(37.5)\end{array}$ & $\begin{array}{l}9 \\
(4.5)\end{array}$ & $\begin{array}{l}82 \\
(41)\end{array}$ & $\begin{array}{l}28 \\
(14)\end{array}$ & 3.26 \\
\hline $\begin{array}{l}\text { 5. Students loan is } \\
\text { only offered to the } \\
\text { poor students. }\end{array}$ & $\begin{array}{l}17 \\
(8.5)\end{array}$ & $\begin{array}{l}34 \\
\text { (17) }\end{array}$ & $\begin{array}{l}2 \\
(1)\end{array}$ & $\begin{array}{l}94 \\
(47)\end{array}$ & $\begin{array}{l}53 \\
(26.5)\end{array}$ & 3.66 & $\begin{array}{l}4 \\
(2)\end{array}$ & $\begin{array}{l}13 \\
(6.5)\end{array}$ & $\begin{array}{l}1 \\
(6.5)\end{array}$ & $\begin{array}{l}117 \\
(58.5)\end{array}$ & $\begin{array}{l}65 \\
(32.5)\end{array}$ & 4.13 \\
\hline $\begin{array}{l}\text { 6. The poor } \\
\text { students have } \\
\text { priority to apply } \\
\text { the student loan. }\end{array}$ & $\begin{array}{l}10 \\
\text { (5) }\end{array}$ & $\begin{array}{l}13 \\
(6.5)\end{array}$ & $\begin{array}{l}0 \\
(0)\end{array}$ & $\begin{array}{l}104 \\
(52)\end{array}$ & $\begin{array}{l}73 \\
(36.5)\end{array}$ & 4.08 & $\begin{array}{l}2 \\
\text { (1) }\end{array}$ & $\begin{array}{l}18 \\
(9)\end{array}$ & $\begin{array}{l}0 \\
(0)\end{array}$ & $\begin{array}{l}149 \\
(74.5)\end{array}$ & $\begin{array}{l}31 \\
(15.5)\end{array}$ & 3.95 \\
\hline $\begin{array}{l}\text { 7. The poor } \\
\text { students have } \\
\text { priority to receive } \\
\text { the student loan. }\end{array}$ & $\begin{array}{l}7 \\
(3.5)\end{array}$ & $\begin{array}{l}57 \\
(28.5)\end{array}$ & $\begin{array}{l}0 \\
(0)\end{array}$ & $\begin{array}{l}106 \\
(53)\end{array}$ & $\begin{array}{l}30 \\
(15)\end{array}$ & 3.48 & $\begin{array}{l}0 \\
(0)\end{array}$ & $\begin{array}{l}12 \\
\text { (6) }\end{array}$ & $\begin{array}{l}0 \\
(0)\end{array}$ & $\begin{array}{l}157 \\
(78.5)\end{array}$ & $\begin{array}{l}31 \\
(15.5)\end{array}$ & 4.04 \\
\hline $\begin{array}{l}\text { 8. Some of loan } \\
\text { receivers are not } \\
\text { exactly poor. }\end{array}$ & $\begin{array}{l}4 \\
\text { (2) }\end{array}$ & $\begin{array}{l}25 \\
(12.5)\end{array}$ & $\begin{array}{l}0 \\
(0)\end{array}$ & $\begin{array}{l}125 \\
(62.5)\end{array}$ & $\begin{array}{l}46 \\
(23)\end{array}$ & 3.92 & $\begin{array}{l}0 \\
(0)\end{array}$ & $\begin{array}{l}95 \\
(47.5)\end{array}$ & $\begin{array}{l}0 \\
(0)\end{array}$ & $\begin{array}{l}87 \\
(43.5)\end{array}$ & $\begin{array}{l}18 \\
(9)\end{array}$ & 3.14 \\
\hline $\begin{array}{l}\text { 9. The rich peers } \\
\text { also can get the } \\
\text { student loan. }\end{array}$ & $\begin{array}{l}4 \\
\text { (2) }\end{array}$ & $\begin{array}{l}18 \\
(9)\end{array}$ & $\begin{array}{l}0 \\
(0)\end{array}$ & $\begin{array}{l}104 \\
(52)\end{array}$ & $\begin{array}{l}74 \\
(37)\end{array}$ & 4.13 & $\begin{array}{l}0 \\
(0)\end{array}$ & $\begin{array}{l}44 \\
(22)\end{array}$ & $\begin{array}{l}0 \\
(0)\end{array}$ & $\begin{array}{l}98 \\
(49)\end{array}$ & $\begin{array}{l}58 \\
(29)\end{array}$ & 3.86 \\
\hline $\begin{array}{l}\text { 10. Student loan is } \\
\text { not provided for } \\
\text { the wealthy peers. }\end{array}$ & $\begin{array}{l}2 \\
\text { (1) }\end{array}$ & $\begin{array}{l}30 \\
(15)\end{array}$ & $\begin{array}{l}0 \\
(0)\end{array}$ & $\begin{array}{l}136 \\
(68)\end{array}$ & $\begin{array}{l}32 \\
(16)\end{array}$ & 3.83 & $\begin{array}{l}0 \\
(0)\end{array}$ & $\begin{array}{l}10 \\
(5)\end{array}$ & $\begin{array}{l}0 \\
(0)\end{array}$ & $\begin{array}{l}97 \\
(48.5)\end{array}$ & $\begin{array}{l}93 \\
(46.5)\end{array}$ & 4.37 \\
\hline
\end{tabular}

Note. $\mathrm{F}=400 ;$ Percentage are in parentheses *Mean value $(\mathrm{M})>3.00$ indicates agree; Mean value $(\mathrm{M})<3.00$ indicates disagree

As can be seen clearly from Table 3, the mean of (3.26) in Malaysia and (3.38) in China shows that most respondents agree that all students in the university are allowed to apply for a student loan. However, the mean of (1.87) in China shows that most respondents disagree with the statement that students have the same opportunity to receive student loan. Alternatively, with the mean (4.11), Malaysian students agree that they have the same opportunity in obtaining a student loan. The mean of (3.63) in both Malaysia and China shows that most of respondents agree with the statement that student loans are only provided based on students' family income status. However, the mean of (3.27) in Malaysia and (3.26) in China also shows that most respondents agree with the statement that student loan is given to excellent students regardless of their income status. Moreover, the mean of (3.66) in Malaysia and (4.13) in China shows that most respondents agree with the statement that student loans are only offered to the poor students; the mean of (4.08) in Malaysia and (3.95) in China shows that most respondents agree that the poor students should be given priority to apply for student loans; and the mean of (3.48) in Malaysia and (4.04) in China shows that most respondents agree that the poor students should be given 


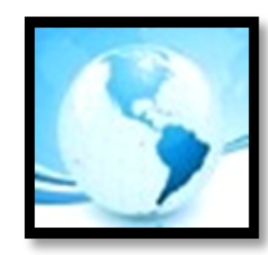

priority to receive student loans. However, the mean of (4.13) in Malaysia and (3.86) in China also shows that most respondents agree with the statement that higher income peers also should obtain student loan.

\section{The Efficiency $f$ Student Loan}

Table 4

Frequency, Percentage and Mean of Efficiency of Student Loan

\begin{tabular}{|c|c|c|c|c|c|c|c|c|c|c|c|c|}
\hline \multirow[t]{2}{*}{ Adequacy } & \multicolumn{6}{|c|}{ MALAYSIA } & \multicolumn{6}{|c|}{ CHINA } \\
\hline & $\begin{array}{l}\text { SD } \\
\text { F } \\
(\%)\end{array}$ & $\begin{array}{l}\text { D } \\
\text { F } \\
(\%)\end{array}$ & $\begin{array}{l}\mathbf{N} \\
\text { F } \\
(\%)\end{array}$ & $\begin{array}{l}\text { A } \\
\text { F } \\
(\%)\end{array}$ & $\begin{array}{l}\text { SA } \\
\text { F } \\
(\%)\end{array}$ & $\begin{array}{l}\text { Mean } \\
\text { F } \\
(M)\end{array}$ & $\begin{array}{l}\text { SD } \\
\text { F } \\
(\%)\end{array}$ & $\begin{array}{l}\text { D } \\
\text { F } \\
(\%)\end{array}$ & $\begin{array}{l}\mathbf{N} \\
\text { F } \\
(\%)\end{array}$ & $\begin{array}{l}\text { A } \\
\text { F } \\
(\%)\end{array}$ & $\begin{array}{l}\text { SA } \\
\text { F } \\
(\%)\end{array}$ & $\begin{array}{l}\text { Mean } \\
\text { F } \\
(\mathrm{M})\end{array}$ \\
\hline $\begin{array}{l}\text { 1. Provide discounts } \\
\text { for early } \\
\text { repayments. }\end{array}$ & $\begin{array}{l}4 \\
(2)\end{array}$ & $\begin{array}{l}16 \\
(8)\end{array}$ & $\begin{array}{l}0 \\
(0)\end{array}$ & $\begin{array}{l}118 \\
(59)\end{array}$ & $\begin{array}{l}62 \\
(31)\end{array}$ & 4.09 & $\begin{array}{l}0 \\
(0)\end{array}$ & $\begin{array}{l}12 \\
(6)\end{array}$ & $\begin{array}{l}0 \\
(0)\end{array}$ & $\begin{array}{l}142 \\
(71)\end{array}$ & $\begin{array}{l}46 \\
(23)\end{array}$ & 4.11 \\
\hline $\begin{array}{l}\text { 2. Student loan } \\
\text { helps poor students } \\
\text { to access higher } \\
\text { institutions. }\end{array}$ & $\begin{array}{l}3 \\
(1.5)\end{array}$ & $\begin{array}{l}29 \\
(14.5)\end{array}$ & $\begin{array}{l}0 \\
(0)\end{array}$ & $\begin{array}{l}114 \\
(57)\end{array}$ & $\begin{array}{l}54 \\
(27)\end{array}$ & 3.94 & $\begin{array}{l}0 \\
(0)\end{array}$ & $\begin{array}{l}4 \\
(2)\end{array}$ & $\begin{array}{l}0 \\
(0)\end{array}$ & $\begin{array}{l}103 \\
(51.5)\end{array}$ & $\begin{array}{l}93 \\
(46.5)\end{array}$ & 4.43 \\
\hline $\begin{array}{l}\text { 3. Tuition fees } \\
\text { should be disbursed } \\
\text { directly to higher } \\
\text { institutions. }\end{array}$ & $\begin{array}{l}1 \\
(0.5)\end{array}$ & $\begin{array}{l}95 \\
(47.5)\end{array}$ & $\begin{array}{l}0 \\
(0)\end{array}$ & $\begin{array}{l}60 \\
(30)\end{array}$ & $\begin{array}{l}44 \\
(22)\end{array}$ & 3.26 & $\begin{array}{l}47 \\
(23.5)\end{array}$ & $\begin{array}{l}132 \\
(66)\end{array}$ & $\begin{array}{l}0 \\
(0)\end{array}$ & $\begin{array}{l}21 \\
(10.5)\end{array}$ & $\begin{array}{l}0 \\
(0)\end{array}$ & 1.98 \\
\hline $\begin{array}{l}\text { 4. Only money of } \\
\text { living cost should be } \\
\text { given to the } \\
\text { students }\end{array}$ & $\begin{array}{l}5 \\
(2.5)\end{array}$ & $\begin{array}{l}23 \\
(11.5)\end{array}$ & $\begin{array}{l}0 \\
(0)\end{array}$ & $\begin{array}{l}126 \\
(63)\end{array}$ & $\begin{array}{l}46 \\
(23)\end{array}$ & 3.93 & $\begin{array}{l}136 \\
(68)\end{array}$ & $\begin{array}{l}64 \\
(32)\end{array}$ & $\begin{array}{l}0 \\
(0)\end{array}$ & $\begin{array}{l}0 \\
(0)\end{array}$ & $\begin{array}{l}0 \\
(0)\end{array}$ & 1.32 \\
\hline $\begin{array}{l}\text { 5. Student loan } \\
\text { helps parents to } \\
\text { reduce the } \\
\text { economic burden. }\end{array}$ & $\begin{array}{l}9 \\
(4.5)\end{array}$ & $\begin{array}{l}12 \\
(6)\end{array}$ & $\begin{array}{l}0 \\
(0)\end{array}$ & $\begin{array}{l}86 \\
(43)\end{array}$ & $\begin{array}{l}93 \\
(46.5)\end{array}$ & 4.31 & $\begin{array}{l}5 \\
(2.5)\end{array}$ & $\begin{array}{l}58 \\
(29)\end{array}$ & $\begin{array}{l}18 \\
(9)\end{array}$ & $\begin{array}{l}94 \\
(47)\end{array}$ & $\begin{array}{l}25 \\
(12.5)\end{array}$ & 3.13 \\
\hline $\begin{array}{l}\text { 6. Student loan } \\
\text { helps to achieve the } \\
\text { equality of } \\
\text { education. }\end{array}$ & $\begin{array}{l}3 \\
(1.5)\end{array}$ & $\begin{array}{l}16 \\
(8)\end{array}$ & $\begin{array}{l}0 \\
(0)\end{array}$ & $\begin{array}{l}63 \\
(31.5)\end{array}$ & $\begin{array}{l}118 \\
\text { (59) }\end{array}$ & 4.39 & $\begin{array}{l}0 \\
(0)\end{array}$ & $\begin{array}{l}0 \\
(0)\end{array}$ & $\begin{array}{l}0 \\
(0)\end{array}$ & $\begin{array}{l}169 \\
(84.5)\end{array}$ & $\begin{array}{l}31 \\
(15.5)\end{array}$ & 4.16 \\
\hline $\begin{array}{l}\text { 7. Student loan is a } \\
\text { big burden. }\end{array}$ & $\begin{array}{l}3 \\
(1.5)\end{array}$ & $\begin{array}{l}81 \\
(40.5)\end{array}$ & $\begin{array}{l}2 \\
(1)\end{array}$ & $\begin{array}{l}65 \\
(32.5)\end{array}$ & $\begin{array}{l}49 \\
(24.5)\end{array}$ & 3.38 & $\begin{array}{l}1 \\
(0.5)\end{array}$ & $\begin{array}{l}4 \\
(2)\end{array}$ & $\begin{array}{l}0 \\
(0)\end{array}$ & $\begin{array}{l}165 \\
(82.5)\end{array}$ & $\begin{array}{l}30 \\
(15)\end{array}$ & 4.1 \\
\hline $\begin{array}{l}\text { 8. The period of loan } \\
\text { repayment should } \\
\text { not be fixed to } 5 \text { to } \\
10 \text { years. }\end{array}$ & $\begin{array}{l}8 \\
(4)\end{array}$ & $\begin{array}{l}33 \\
(16.5)\end{array}$ & $\begin{array}{l}0 \\
(0)\end{array}$ & $\begin{array}{l}49 \\
(24.5)\end{array}$ & $\begin{array}{l}110 \\
(55)\end{array}$ & 4.1 & $\begin{array}{l}3 \\
(1.5)\end{array}$ & $\begin{array}{l}45 \\
(22.5)\end{array}$ & $\begin{array}{l}0 \\
(0)\end{array}$ & $\begin{array}{l}104 \\
(52)\end{array}$ & $\begin{array}{l}48 \\
(24)\end{array}$ & 3.75 \\
\hline
\end{tabular}




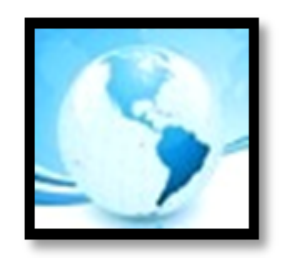

MALAYSIAN ONLINE JOURNAL OF EDUCATIONAL MANAGEMENT (MOJEM)

\begin{tabular}{|c|c|c|c|c|c|c|c|c|c|c|c|c|}
\hline $\begin{array}{l}\text { 9. Repayment } \\
\text { should not be } \\
\text { imposed if the } \\
\text { borrowers' income } \\
\text { is below the } \\
\text { threshold. }\end{array}$ & $\begin{array}{l}9 \\
(4.5)\end{array}$ & $\begin{array}{l}22 \\
(11)\end{array}$ & $\begin{array}{l}0 \\
(0)\end{array}$ & $\begin{array}{l}58 \\
(29)\end{array}$ & $\begin{array}{l}111 \\
(55)\end{array}$ & 4.2 & $\begin{array}{l}9 \\
(4.5)\end{array}$ & $\begin{array}{l}171 \\
(85.5)\end{array}$ & $\begin{array}{l}0 \\
(0)\end{array}$ & $\begin{array}{l}20 \\
(10)\end{array}$ & $\begin{array}{l}0 \\
(0)\end{array}$ & 2.16 \\
\hline $\begin{array}{l}\text { 10. Repayment } \\
\text { should depend on } \\
\text { the borrowers' } \\
\text { salaries. }\end{array}$ & $\begin{array}{l}3 \\
(1.5)\end{array}$ & $\begin{array}{l}20 \\
(10)\end{array}$ & $\begin{array}{l}0 \\
(0)\end{array}$ & $\begin{array}{l}119 \\
(59.5)\end{array}$ & $\begin{array}{l}58 \\
(29)\end{array}$ & 4.05 & $\begin{array}{l}3 \\
(1.5)\end{array}$ & $\begin{array}{l}73 \\
(36.5)\end{array}$ & $\begin{array}{l}8 \\
(4)\end{array}$ & $\begin{array}{l}81 \\
(40.5)\end{array}$ & $\begin{array}{l}35 \\
(17.5)\end{array}$ & 3.36 \\
\hline
\end{tabular}

Note. $\mathrm{F}=400$; Percentage are in parentheses *Mean value $(\mathrm{M})>3.00$ indicates agree; Mean value $(\mathrm{M})<3.00$ indicates disagree

As can be seen in Table 4, the mean of (3.94) in Malaysia and (4.43) in China shows that most of the respondents agree with the statement that student loans help low-income family students to access higher institutions. The mean of (4.31) in Malaysia and (3.13) in China also shows that most respondents agree that student loans help parents to reduce the economic burden. And the mean of (4.39) in Malaysia and (4.16) in China also shows that most respondents agree that student loans help to achieve education equality. For the repayment of student loans, the mean of (3.38) in Malaysia and (4.10) in China shows that most respondents agree that student loan repayment is a big burden that affects the borrowers' decision making in the daily life. Therefore, the mean of (4.10) in Malaysia and (3.75) in China shows that most of the respondents agree that the period of loan repayment should not be fixed to 5 to 10 years; the mean of (4.05) in Malaysia and (3.36) in China also shows that most of respondents agree that the amount of loan repayment should depend on the borrowers' salaries. However, the mean of (2.16) in China shows that most of respondents disagree with the statement that student loan repayment should not be imposed if the borrowers' income is below the threshold, in comparison to the mean of (4.20) in Malaysia. Accordingly, the mean of (4.09) in Malaysia and (4.11) in China also shows that most respondents agree that a discount should be provided for early repayment.

\section{The Related Issues of student loan}

Table 5

Frequency, Percentage and Mean of Issues and Challenges of Student Loan

\begin{tabular}{|c|c|c|c|c|c|c|c|c|c|c|c|c|}
\hline \multirow[t]{4}{*}{ Adequacy } & \multicolumn{6}{|c|}{ MALAYSIA } & \multicolumn{6}{|c|}{ CHINA } \\
\hline & SD & D & $\mathbf{N}$ & $\mathbf{A}$ & SA & Mean & SD & D & $\mathbf{N}$ & $\mathbf{A}$ & SA & Mean \\
\hline & $\mathrm{F}$ & $\mathrm{F}$ & $\mathrm{F}$ & $\mathrm{F}$ & F & & $\mathrm{F}$ & $\mathrm{F}$ & $\mathrm{F}$ & $\mathrm{F}$ & $\mathrm{F}$ & \\
\hline & $(\%)$ & $(\%)$ & $(\%)$ & $(\%)$ & $(\%)$ & $(\mathrm{M})$ & $(\%)$ & $(\%)$ & $(\%)$ & $(\%)$ & $(\%)$ & $(\mathrm{M})$ \\
\hline $\begin{array}{l}\text { 11. Students should } \\
\text { not be burdened } \\
\text { with debt. }\end{array}$ & $\begin{array}{l}0 \\
(0)\end{array}$ & $\begin{array}{l}1 \\
(0.5)\end{array}$ & $\begin{array}{l}0 \\
(0)\end{array}$ & $\begin{array}{l}92 \\
(46.0)\end{array}$ & $\begin{array}{l}107 \\
(53.5)\end{array}$ & 4.53 & $\begin{array}{l}0 \\
(0)\end{array}$ & $\begin{array}{l}0 \\
(0)\end{array}$ & $\begin{array}{l}0 \\
(0)\end{array}$ & $\begin{array}{l}83 \\
(41.5)\end{array}$ & $\begin{array}{l}117 \\
(58.5)\end{array}$ & 4.59 \\
\hline
\end{tabular}




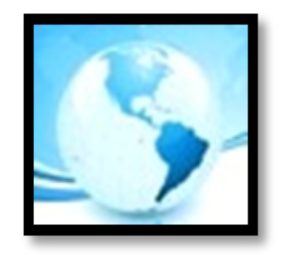

MALAYSIAN ONLINE JOURNAL OF

EDUCATIONAL MANAGEMENT

(MOJEM)

\begin{tabular}{|c|c|c|c|c|c|c|c|c|c|c|c|c|}
\hline $\begin{array}{l}\text { 2. The interest rate } \\
\text { should not be } \\
\text { imposed for the poor } \\
\text { borrowers }\end{array}$ & $\begin{array}{l}1 \\
(0.5)\end{array}$ & $\begin{array}{l}12 \\
(6)\end{array}$ & $\begin{array}{l}0 \\
(0)\end{array}$ & $\begin{array}{l}122 \\
(61)\end{array}$ & $\begin{array}{l}65 \\
(32.5)\end{array}$ & 4.19 & $\begin{array}{l}0 \\
(0)\end{array}$ & $\begin{array}{l}0 \\
(0)\end{array}$ & $\begin{array}{l}0 \\
(0)\end{array}$ & $\begin{array}{l}191 \\
(95.5)\end{array}$ & $\begin{array}{l}9 \\
(4.5)\end{array}$ & 4.05 \\
\hline $\begin{array}{l}\text { 3. Student loan } \\
\text { default is due to the } \\
\text { borrowers' negative } \\
\text { attitude in repaying. }\end{array}$ & $\begin{array}{l}10 \\
(5)\end{array}$ & $\begin{array}{l}61 \\
(30.5)\end{array}$ & $\begin{array}{l}0 \\
(0)\end{array}$ & $\begin{array}{l}41 \\
(20.5)\end{array}$ & $\begin{array}{l}88 \\
(44.0)\end{array}$ & 3.68 & $\begin{array}{l}0 \\
(0)\end{array}$ & $\begin{array}{l}0 \\
(0)\end{array}$ & $\begin{array}{l}0 \\
(0)\end{array}$ & $\begin{array}{l}147 \\
(73.5)\end{array}$ & $\begin{array}{l}53 \\
(26.5)\end{array}$ & 2.3 \\
\hline $\begin{array}{l}\text { 4. Student loan } \\
\text { default is due to the } \\
\text { weakly family } \\
\text { economic support. }\end{array}$ & $\begin{array}{l}0 \\
(0)\end{array}$ & $\begin{array}{l}2 \\
(1)\end{array}$ & $\begin{array}{l}0 \\
(0)\end{array}$ & $\begin{array}{l}78 \\
(39)\end{array}$ & $\begin{array}{l}120 \\
(60)\end{array}$ & 4.58 & $\begin{array}{l}10 \\
(5)\end{array}$ & $\begin{array}{l}159 \\
(79.5)\end{array}$ & $\begin{array}{l}0 \\
(0)\end{array}$ & $\begin{array}{l}24 \\
(12)\end{array}$ & $\begin{array}{l}7 \\
(3.5)\end{array}$ & 4.27 \\
\hline $\begin{array}{l}\text { 5. Student loan } \\
\text { default is due to the } \\
\text { burden of continuous } \\
\text { debt. }\end{array}$ & $\begin{array}{l}1 \\
(0.5)\end{array}$ & $\begin{array}{l}3 \\
(1.5)\end{array}$ & $\begin{array}{l}1 \\
(0.5)\end{array}$ & $\begin{array}{l}84 \\
(42)\end{array}$ & $\begin{array}{l}111 \\
(55.5)\end{array}$ & 4.51 & $\begin{array}{l}0 \\
(0)\end{array}$ & $\begin{array}{l}0 \\
(0)\end{array}$ & $\begin{array}{l}0 \\
(0)\end{array}$ & $\begin{array}{l}165 \\
(82.5)\end{array}$ & $\begin{array}{l}35 \\
(17.5)\end{array}$ & 4.18 \\
\hline $\begin{array}{l}\text { 6. Student loan } \\
\text { default is due to the } \\
\text { highly rate of } \\
\text { unemployment. }\end{array}$ & $\begin{array}{l}0 \\
(0)\end{array}$ & $\begin{array}{l}7 \\
(3.5)\end{array}$ & $\begin{array}{l}0 \\
(0)\end{array}$ & $\begin{array}{l}79 \\
(38)\end{array}$ & $\begin{array}{l}117 \\
(58.5)\end{array}$ & 4.52 & $\begin{array}{l}0 \\
(0)\end{array}$ & $\begin{array}{l}0 \\
(0)\end{array}$ & $\begin{array}{l}0 \\
(0)\end{array}$ & $\begin{array}{l}153 \\
(76.5)\end{array}$ & $\begin{array}{l}47 \\
(23.5)\end{array}$ & 4.24 \\
\hline $\begin{array}{l}\text { 7. Income contingent } \\
\text { loan is a better } \\
\text { approach for } \\
\text { repayments. }\end{array}$ & $\begin{array}{l}0 \\
(0)\end{array}$ & $\begin{array}{l}13 \\
(6.5)\end{array}$ & $\begin{array}{l}0 \\
(0)\end{array}$ & $\begin{array}{l}128 \\
(64)\end{array}$ & $\begin{array}{l}59 \\
(29.5)\end{array}$ & 4.17 & $\begin{array}{l}12 \\
(6)\end{array}$ & $\begin{array}{l}90 \\
(45)\end{array}$ & $\begin{array}{l}0 \\
(0)\end{array}$ & $\begin{array}{l}65 \\
(32.5)\end{array}$ & $\begin{array}{l}33 \\
(16.5)\end{array}$ & 3.09 \\
\hline $\begin{array}{l}\text { 8. Loan default can } \\
\text { be achieved by the } \\
\text { government's } \\
\text { enforcement. }\end{array}$ & $\begin{array}{l}1 \\
(0.5)\end{array}$ & $\begin{array}{l}16 \\
(8)\end{array}$ & $\begin{array}{l}0 \\
(0)\end{array}$ & $\begin{array}{l}89 \\
(44.5)\end{array}$ & $\begin{array}{l}94 \\
(47)\end{array}$ & 4.3 & $\begin{array}{l}1 \\
(0.5)\end{array}$ & $\begin{array}{l}50 \\
(25)\end{array}$ & $\begin{array}{l}0 \\
(0)\end{array}$ & $\begin{array}{l}113 \\
(56.5)\end{array}$ & $\begin{array}{l}36 \\
(18)\end{array}$ & 3.67 \\
\hline $\begin{array}{l}\text { 9. Social media plays } \\
\text { its role to influence } \\
\text { the borrowers to pay } \\
\text { back the loan. }\end{array}$ & $\begin{array}{l}0 \\
(0)\end{array}$ & $\begin{array}{l}21 \\
(10.5)\end{array}$ & $\begin{array}{l}0 \\
(0)\end{array}$ & $\begin{array}{l}146 \\
(73)\end{array}$ & $\begin{array}{l}33 \\
(16.5)\end{array}$ & 3.96 & $\begin{array}{l}0 \\
(0)\end{array}$ & $\begin{array}{l}37 \\
(18.5)\end{array}$ & $\begin{array}{l}0 \\
(0)\end{array}$ & $\begin{array}{l}128 \\
(64)\end{array}$ & $\begin{array}{l}35 \\
(17.5)\end{array}$ & 3.81 \\
\hline $\begin{array}{l}\text { 10. The moral } \\
\text { education should be } \\
\text { provided in the } \\
\text { University to } \\
\text { strengthen students' } \\
\text { conscious in the loan } \\
\text { repayment. }\end{array}$ & $\begin{array}{l}0 \\
(0)\end{array}$ & $\begin{array}{l}11 \\
(5.5)\end{array}$ & $\begin{array}{l}0 \\
(0)\end{array}$ & $\begin{array}{l}147 \\
(73.5)\end{array}$ & $\begin{array}{l}42 \\
(21)\end{array}$ & 4.1 & $\begin{array}{l}0 \\
(0)\end{array}$ & $\begin{array}{l}15 \\
(7.5)\end{array}$ & $\begin{array}{l}0 \\
(0)\end{array}$ & $\begin{array}{l}131 \\
(65.5)\end{array}$ & $\begin{array}{l}54 \\
(27)\end{array}$ & 4.12 \\
\hline
\end{tabular}

Note. $\mathrm{F}=400 ;$ Percentage are in parentheses *Mean value $(\mathrm{M})>3.00$ indicates agree; Mean value $(\mathrm{M})<3.00$ indicates disagree 
As can be seen from Table 5, the mean of (3.68) in Malaysia and (4.27) in China shows that most respondents agree that student loan default is due to borrowers' negative attitude in repaying. However, the mean of (2.30) in China shows that most respondents disagree that student loan default is due to weakly family economic support compared with the mean of (4.58) in Malaysia. Moreover, the mean of (4.51) in Malaysia and (4.18) in China shows that most respondents agree that student loan default is due to the burden of continuous debt; the mean of (4.52) in Malaysia and (4.24) in China also shows that most respondents agree that student loan default is due to high rate of unemployment. Therefore, the mean of (4.30) in Malaysia and (3.67) in China shows that most respondents agree that the loan default can be achieved by the government's enforcement; the mean of (3.96) in Malaysia and (3.81) in China shows that most respondents agree that social media plays its role to influence borrowers to pay back the loan, and the mean of (4.10) in Malaysia and (4.12) in China also shows that most of respondents agree that moral education should be provided in the University to strengthen students' consciousness in the loan repayment. Moreover, the mean of (4.53) in Malaysia and (4.59) in China shows that most respondents agree that students should not be burdened with debt.

Research Question 2: What are the factors that determine the adequacy of student loans in Malaysia and China?

Logistic regression has been applied since the dependent variable is a binary outcome ( 1 is adequate, 0 is not adequate). After the logistic regression, marginal effects have been determined using STATA.

Table 6

Description of Variables and Logistic Regression Analysis

\begin{tabular}{|c|c|}
\hline $\begin{array}{l}\text { Variables } \\
\text { Dependent variables : } \\
\text { The Adequacy of Financial Aid }\end{array}$ & $\mathrm{No}=0$ \\
\hline \multicolumn{2}{|l|}{ Independent variable : } \\
\hline 1. Male & No=Female \\
\hline 2. Malaysian & No=Chinese \\
\hline 3. Monthly living expenses 400 and more & No=Less than 400 \\
\hline 4. Fees less than 2000 & No=More than 2000 \\
\hline 5. Science engineering & No=Others \\
\hline 6. Parent education degree above & No=Under degree \\
\hline 7. Number of siblings more than 2 & No=Below 2 \\
\hline 8. Parental income 2000 above & No=Less than 2000 \\
\hline 9. Financial aid & $\mathrm{No}=$ Never get \\
\hline
\end{tabular}




\begin{tabular}{lll} 
& \multicolumn{2}{c}{} \\
\cline { 2 - 3 } The Adequacy of Financial Aid & Marginal effects & Std.Err. \\
\hline Male & -0.003 & 0.05395 \\
Malaysian & $0.144^{* *}$ & 0.07036 \\
Monthly living expenses 400 and more & $0.106^{*}$ & 0.06187 \\
Fees less than 2000 & $0.137^{* *}$ & 0.05248 \\
Science and Engineering & 0.065 & 0.05219 \\
Parental income 2000 above & $0.121^{* *}$ & 0.05634 \\
Number of siblings more than 2 & $0.132^{*}$ & 0.07107 \\
Parents' education degree above & -0.064 & 0.06271 \\
Financial aid & 0.241 & 0.05534 \\
Pseudo R2 & & \\
Number of observations & 0.158 & \\
\hline
\end{tabular}

Note: $* * *$ at 1 percent, $* *$ at 5 percent,

The findings in Table 6 above, indicate that gender; types of program that the students are enrolled in, number of siblings, parental education are not important factors in determining the adequacy of student loans in China and Malaysia. The results show that the null hypothesis for nationality is rejected meaning nationality is an important factor in determining the adequacy of student loan in Malaysia and China. On average, Malaysian students are 14.41 percent more likely to indicate adequacy of financial aid compared to Chinese students, holding all other variables constant.

The results show that the null hypothesis for tuition fees is rejected meaning tuition fees are an important factor in determining the adequacy of student loans in Malaysia and China. On average, those students whose tuition fees are less than 2000 are 13.68 percent more likely to indicate adequacy of financial aid compared to those students whose tuition fees are more than 2000 , holding all other variables constant.

The results show that the null hypothesis for parental income is rejected meaning parental income is an important factor in determining the adequacy of student loans in Malaysia and China. On average, those students whose parental income is 2000 above are $\mathbf{1 2 . 1 0}$ percent more likely to indicate adequacy of financial aid compared to those students whose parental income is less than 2000, holding all other variables constant. 


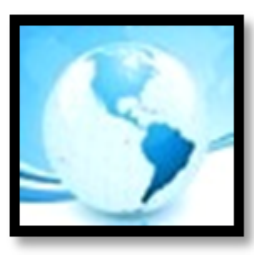

\section{MALAYSIAN ONLINE JOURNAL OF EDUCATIONAL MANAGEMENT (MOJEM)}

The results show that the null hypothesis for financial aid is rejected meaning financial aid is an important factor in determining the adequacy of student loans in Malaysia and China. On average, those students who received financial aid before are 24.13 percent more likely to indicate adequacy of financial aid compared to those students who had never received financial aid before, holding all other variables constant.

\section{DISCUSSION}

Student loans are one of the important financial aids advocated by both the government and universities in Malaysia and China in recent years. Due to the increasing tuition fees that affect the ability of students from lowincome families to attend higher education, student loans can be used to encourage the enrollment of students regardless of their economic status. Therefore, it is important to identify the challenges encountered related to student loans in terms of adequacy, equity, efficiency and related issues in Malaysia and China. Additionally, this study also analyses the factors that determine adequacy in student loans in Malaysia and China.

In terms of adequacy, the findings indicate that the amount of student loan is not adequate to cover both tuition fees and living expenses in both Malaysia and China. Even though, part of the educational-related expenditures can be shared by the student loan, but students' family still has to take the responsibility to cover the unsolved fees. This is burdensome especially for low and middle-income families. Such pressure may cause students to drop out of university. Therefore, the amount of student loan for low and middle income students still needs to be increased to ensure students are provided with sufficient funding.

In terms of equity, all students in Malaysia and China are allowed to apply for student loans which mean that all students have the same opportunity in applying for the loan. However, most respondents in China indicated that they don't have the same opportunity to receive the loan. This is because the distribution of student loans in China generally is done electorally. Since the government distributes the fund of student loan to higher institutions, the students are required to apply for the loan from the higher intuitions. Higher institutions as the loan distribution agency have the authority to choose the students who are eligible to receive the loan. Therefore, the appliers who have established a good relationship with the electors will have a higher opportunity of receiving the loan. It means that the distribution of student loans in China lacks the standard of transparency (Feng, 2009). Moreover, most respondents in this study also indicated that the wealthy peers are also entitled to receive student loans. This is due to the rising number of upper-income students who apply for student loans. For the wealthy peers, the amount of student loan provides them with additional funding. Thus, these students can spend the money which is provided by their parents.

In terms of efficiency, the findings indicate that in both Malaysia and China, student loan repayment is a big burden that affects the borrowers' decision making in the daily life. Therefore, most respondents indicate that the amount of loan repayment should depend on the borrowers' salaries.

Since the issue of loan default is occurred, many previous studies have investigated the reasons for loan default. Some of the reasons for loan default are higher rates of unemployment (Woo, 2002a, 2002b); borrowers' negative attitude on repaying the loan (Bertola \& Hochguertel, 2005); weak family economic support (Herr \& Burt, 2005; Steiner \& Teszler, 2005) and the continuous debt (Schwartz \& Finnie, 2002). Likewise, the finding of this study has also found that most respondents in both Malaysia and China mentioned that the student loan default is due to 


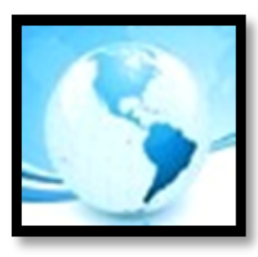

\section{MALAYSIAN ONLINE JOURNAL OF EDUCATIONAL MANAGEMENT (MOJEM)}

those four reasons above. In order to achieve the issue of loan default, some countries have tried to implement the Income Contingent Loan. According to Chapman (2006a, 2006b); Income Contingent Loan is a loan in which the repayment depends on the future income status of the borrowers. It is more manageable so that the borrowers can complete the repayment ultimately. Likewise, the finding of this study also shows that most of respondents in both Malaysia and China agree that Income Contingent Loan is a better approach for repayments. Moreover, the finding of this study has also found that the loan repayment default can be achieved by the government's enforcement, supervision through social media and also the moral education which is provided by the university.

Additionally, the findings indicate that the nationality, tuition fees, parental income and financial aids are important determinants of adequacy of student loan. Thus, it is important to consider various factors when distributing financial assistance to students.

\section{CONCLUSION}

All children regardless of socio-economic status should be given equality of opportunity to pursue tertiary education. Student loan plays an important role in increasing access to tertiary education especially among low income families. Policy makers need to ensure that these students are provided sufficient funding to continue and complete their higher education. Policy-makers should concentrate on policy formulation to ensure the implementation of student loans can be more effective. Appropriate actions need to be taken to ensure the information of student loans is disseminated to the public through media. Policy makers and various stakeholders should play their role to ensure the student loans in both Malaysia and China achieve equity, efficiency and adequacy.

\section{ACKNOWLEDGEMENT:}

This research was funded by the grant of Fundamental Research Grant Scheme (FRGS), the Ministry of Education, Malaysia (FP017-2104A).

\section{REFERENCE}

Association of Independent Institutions. (2009). Independent Institutions: The Booming Section of Higher Education in China. Retrieved from http://www.dixy.org/article_show.asp?id=165

Bakar, E. A., Masud, J., \& Jusoh, Z. M. (2006). Knowledge, attitude and perceptions of university students towards educational loans in Malaysia. Journal of family and economic issues, 27(4), 692-701.

Barr, N. (2001). Funding higher education: policies for access and quality.House of Commons Education and Skills Committee, Post-16 student support, Session, 2, 24. 


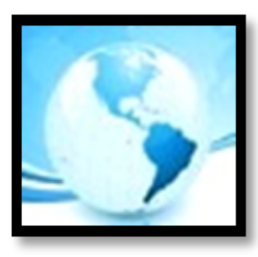

\section{MALAYSIAN ONLINE JOURNAL OF EDUCATIONAL MANAGEMENT (MOJEM)}

Baum, S., \& Malley, M. (2003). College on credit: How borrowers perceive their education debt. Results of the 2002 National Loan Survey. Braintree, MA: Nellie Mae Corporation.

Baum, S., \& Payea, K. (2004). Education Pays. Journal of Educational Management. 5, 45-47.

Bertola, G., \& Hochguertel, S. (2005) Household Debt and Credit. Published Master Dissertation, European University Institute.

Creswell, J. W. (2013). Research design: Qualitative, quantitative, and mixed methods approaches. Sage publications.

Chapman, B. (2006a). Government Managing Risk: Income Contingent Loans for Social and Economic Progress. London: Routledge.

Chapman, B. (2006b). Income Related Student Loans: Concepts, International Reforms and Administrative Challenges. In Teixeira, Pedro N, Johnstone, D. B., Rosa, M., and Vossensteyn, H. Eds. Cost-Sharing and Accessibility in Higher Education: A Fairer Deal (pp. 79-104). Dordrecht the Netherlands: Springer, 2006.

Choy, S. P., \& Li, X. (2006). Dealing with debt: 1992-93 bachelor's degree recipients 10 years later (NCES 2006156). Washington, DC: US Department of Education, National Center for Education Statistics.

Cunningham, Alisa F. and Kienzl, Gregory S. "Delinquency: The Untold Story of Student Loan Borrowing." Washington, DC: Institute for Higher Education Policy, Retrieved from http://www.asa.org/pdfs/corporate/delinquency_the_untold_story.pdf.

Dill, D. D., \& Vught, F. A. (2010). National innovation and the academic research enterprise: Public policy in global perspective. Baltimore: The Johns Hopkins University Press.

Executive Office of the President. (2014). Increasing college opportunities for low-income students: Promising models and a call to action. Washington, DC: The White House.

Feng.T (2009): The investigation of Student Loan Program in China. ISBN 978-7-80745-526-4.

Gross, J. P. ., Cekic, O., Hossler, D., \& Hillman, N. (2009). What Matters in Student Loan Default: A Review of the Research Literature. Journal of Student Financial Aid, 39(1), 19-29.

Herr, E., \& Burt, L. (2005). Predicting student loan default for the University of Texas at Austin. Journal of Student Financial Aid, 35(2), 27-49.

Hossler, D., Gross, J. P., \& Ziskin, M. (2006). A multi-institution analysis of the effects of campus-based financial aid on student persistence at public four-year institutions. Bloomington: Indiana University.

Ishengoma, J. M. (2004). Cost sharing and Participation in Higher Education in Sub-Saharan Africa: The case of Tanzania. Published Doctoral dissertation. State University of New York at Buffalo.

Ismail, S., Serguieva, A. and Singh, S., (2010) Student loan repayment in Malaysia: An exploratory study, Doctoral Symposium, March 04-05, 2010, Brunel University, United Kingdom. 


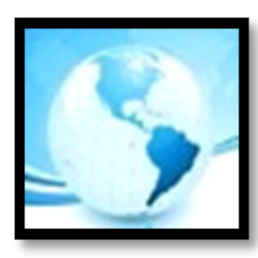

\section{MALAYSIAN ONLINE JOURNAL OF EDUCATIONAL MANAGEMENT (MOJEM)}

Johnstone, D. B. (2006). Financing Higher Education: Cost-Sharing in International Perspective: Center for International Higher Education Lynch School of Education. Boston College Chestnut Hill, Massachusetts.

Johnstone, D. B., \& Marcucci, P. (2010). Financing higher education in International perspective: who pays? Who should pay? Baltimore: The Johns Hopkins University Press.

Liu, X., Luo, R., Liu, C., \& Zhang, L. (2007). The cost of going to senior high schools in rural China. Working Paper WP-07-C8, Northwest Socio-economic Development Research Center, Shaanxi, China. Levy, D. C. (2010).

East Asian private higher education: Reality and policy. Draft for Discussion. New York: University at Albany-SUNY.

Macmillan P. (2006). Higher Education in The World, The Financing of Universities. Great Britain, William cloves, First edition.

Ministry of Education. China. (2006). Changes in Higher Education Enrolment. Retrieved June 7, 2014, from http://www.moe.gov.cn/edoas/website 18/53/info33553.htm

Ministry of Education Malaysia (MOE). (2015). Malaysia Education Blueprint 2015-2025 (Higher Education). Retrieved from : http://www.moe.gov.my/cms/upload_files/articlefile/2013/articlefile_file_003108.pdf

Ministry of Higher Education (MoHE) (2010), Available online at http://www.mohe.gov.my [Accessed April 2, 2010].

Mishory, J., \& Sullivan, R. (2012). The impact of student debt on the ability to buy a house. Young Invincibles. Retrieved from http://younginvincibles.org/wp-content/uploads/2012/08/Denied-The-Impact-of-StudentDebt-on-the-Ability-to-Buy-a-House-8.14.12.pdf

Nyahende, V. R. (2013). The success of students' loans in financing higher education in Tanzania. The Journal of Higher Education studies, 3(3), 47-61. Retrieved from http://dx.doi.org/10.5539/hes.v3n3p47

Pavel, A.P., (2012), The Importance of Quality in Higher Education in an Increasingly Knowledge-Driven Society in International Journal of Academic Research in Accounting, Finance and Management Sciences Volume 2, Special Issue 1 (2012), pp. 120-127

Schwartz, S., \& Finnie, R. (2002). Student loans in Canada: An analysis of borrowing and repayment. Economics of Education Review, 21(5), 497-512.

Shen, H., \& Li, W. (2003). A review of the student loans scheme in China. UNESCO Bangkok.

Seifert, C. F., \& Worden, L. (2004). Two studies assessing the effectiveness of early intervention on the default behaviour of student loan borrowers. Journal of Student Financial Aid, 34(3), 41-52.

Shen, H., \& Ziderman, A. (2009). Student loans repayment and recovery: international comparisons. Higher education, 57(3), 315-333.

Steiner, M., \& Teszler, N. (2005). Multivariate analysis of student loan defaulters at Texas A\&M University. Austin, TX: Texas Guaranteed Student Loan Corporation. 


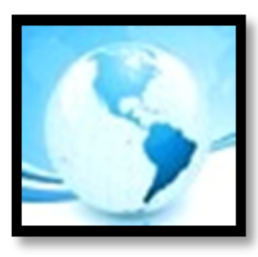

MALAYSIAN ONLINE JOURNAL OF

EDUCATIONAL MANAGEMENT

(MOJEM)

UNESCO. (2009). UNESCO Portal on Higher Education Institutions. Retrieved from:http://portal.unesco.org/education/en/ev.php-

URL_ID=49864\&URL_DO=DO_TOPIC\&URL_SECTION=201.html on 1 April 2009.

UNDP (2012), World Population Prospects: The 2010 Revision. http://esa.un.org/unpd/wpp/index.htm.

Wang, R., Wei, J., Yang, P., and Yi, Q. (2008). Chinese Higher Education Finance: Issues and Challenges. Paper presented at the Financing Higher Education and Economic Development in East Asia, Bangkok, Thailand .

Woo, J. (2002). Factors affecting the probability of default: Student loans in California. Journal of student financial Aid, 32(2), 5-23.

Woo, J. H. (2002a). Clearing accounts: The causes of student loan default. Rancho Cordova, CA: EdFund.

Woo, J. H. (2002b). Factors affecting the probability of default: Student loans in California. Journal of Student Financial Aid, 32(2), 5-23.

Woodhall, M. (2007). Funding Higher Education; The contribution of Economic Thinking to Debate and policy development. Washington, DC: World Bank.

World Bank. (2008a). Accelerating catch-up: Tertiary Education for Growth in Subsaharan Africa. World Bank, Washington, DC.

World Bank Group (Ed.). (2012). World development indicators 2012. World Bank Publications.

Zeng, D. Z., \&Wang, S. (2007). China and the Knowledge Economy: Challenges and Opportunities. World Bank Policy Research Working Paper.

Zhang, J. (2008, September). ASEAN Higher Education on the Road from Elite to Massification. Conference paper for the Asia-Pacific Sub-regional Preparatory Conference for the 2009 World Conference for Higher Education. Macao SAR, PR China.

Ziderman, A. (2002). Alternative objectives of national student loan schemes: Implications for design, evaluation and policy. Welsh Journal of Education, 11(1), 37-47.

Ziderman, A. (2003). Student loans in Thailand: are they effective, equitable, sustainable. Bangkok: IIEP; UNESCO Bangkok.

Ziderman, A. (2004). FinancingUniversities in Developing Countries, Stanford Series on Education and Public Policy. London Press. 